\title{
On the Relation of the Osmotic Value of Cell-sap of Mosses with Environmental Factors I*
}

\author{
By Harumi OCHI** and Sadao YoneHaRA***
}

越智春美・米原貞男： 蘚類の細胞液滲透価と環境との関係について 第一報

\author{
Received July 2, 1954
}

During these several years, the senior author has been occupied some of his times in autecological studies of water relations of mosses. Preliminarily he has published some results of osmotic determinations ${ }^{5)}$. Bender has published also a report on this problem, and his results were cited in "Verdoorn's Manual of Bryolog $y^{\prime \prime 3)}$ that the osmotic values is higher in protonema and older parts, and environment seems to give no appreciable influence. Up to the present, we have few valuable works on the relationships between the osmotic value and environmental factors. Ochi and Iwanaga ${ }^{8)}$ found with Mnium Maximowiczii Lindb. that the osmotic value seemed to ascend by the temperature fall and descend by the temperature rise. In this case, however, the determination was carried out only twice, that is, in summer and in winter. With respect to water and mineral relations, Buch ${ }^{2}$ has distinguished endohydric and ectohydric mosses, and we are able to suppose that the osmotic relations in the former may be different from those in the latter.

In the present paper; the authors can represent on some detailed investigations with two pollacauophytic ${ }^{2)}$ and one endohydric mesophytic ${ }^{2)}$ species, giving special references to the seasonal fluctuation of the osmotic value, differences between the values obtained on fine and rainy days in the same season, and fluctuations represented when the material is kept air-dried in the room.

\section{Materials and Methods}

Materials were collected from the vicinities of Tottori City. Their names and habitats are as follows: Hedwigia albicans (Web.) Lindb., on the rock at a slightly sunny place; Neckera humilis Mitt., on the bark of a tree-trunk in fortest; and

\footnotetext{
* This paper is the graduation thesis of the junior author, and was read at the 4th Annual Meeting of the Chûgoku-Shikoku Branch of the Botanical Society of Japan at Kôchi University, May (1953).

** Biological Institute, Faculty of Liberal Arts, Tottori University. 鳥取大学学芸学部生物学教窒

*** Kasumi Upper Middle School, Kasumi-chô, Kinosaki-gun, Hyôgo Pref. 兵庫県立香住高等学校
} 
Polytrichum attenuatum Menz., on the soil covering the rock in slightly sunny forest.

In each experiment, similar individuals were selected from places under similar conditions as far as possible. Collected materials were put into a tubelike glass bottle, ca. $12 \times 2.7 \mathrm{~cm}$, and firmly stoppered, and carried to the laboratory. Four leaves at ca. 1/3 distance from the top of the annual shoots were excised. And they were immediately immersed in a series of $\mathrm{NaNO}_{3}$ solutions in $0.02 \mathrm{~N}$ intervals. Incipient plasmolysis value was determined at the leaf-base, and the average of 4 measurements was taken.

\section{Experimental Results}

Experiment 1. Seasonal fluctuations. The material was collected towards the end of every month, on a fine day which was followed three days after a rain fall. From December to January, however, the materials were obliged to be collected on rainy or very humid days because the interval was a rainy period in out district.

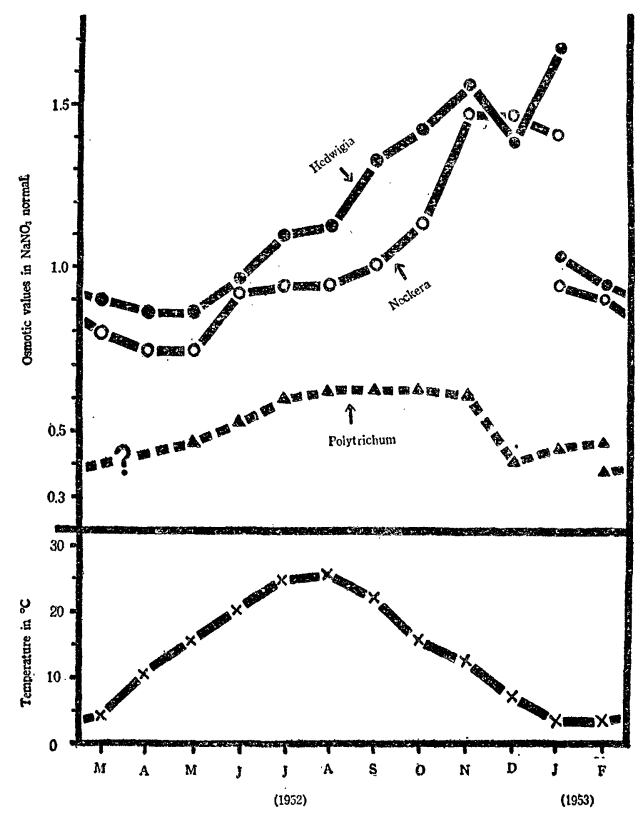

Fig. 1. Seasonal fluctuations of the osmotic value at incipient plasmolysis and mean monthly temperature.

New shoots of Hedwigia and Neckera come out in January and as indicated in Fig. 1, their osmotic values become slightly lowered from January to April or May. And they ascend steeply thereafter to June or July, and stops to ascend for a while, then continue to ascend again remarkably until winter. On the other hand, in Polytrichum, new plants appear in February and the osmotic value ascends slightly from that time to May, and then it ascends gently until August, held almost constant until November, thereafter descends till February. Differences between the minimum and maximum values in Hedwigia and Neckera are larger than in Polytrichum.

Experiment 2. The osmotic values on fine and rainy days. As shown in Fig. 2, the osmotic values are higher on fine days than on rainy days, and the difference between the two cases is larger in Hedwigia and Neckera than in Polytrichum. But even in Polytrichum, it ascends remarkably at dry interval in July and descends remarkably at the next rainy interval.

Experiment 3. Fluctuations of the osmotic value in Hedwigia kept air-dried in the room. The material collected on April 13, rainy was left air-dried in the 
room, and the osmotic value was determined with solutions of $\mathrm{NaNO}_{3}$ at intervals of several days. And for comparison, the same measurement was made with materials collected from the natural habitat as the control (Fig. 3). The value of the air-dried material increased conspicuously in the first several days, then, reached a constant level gradually. The material dried up after about 13 weeks' airdrying, and at the end of the experiment, the value became approximately twice as high as the value at the beginning.

Experiment 4. As reported by Brauner ${ }^{1)}$ and Patterson ${ }^{9}$, there has been some obstructions on the plasmolysis in mosses, and Ochi4), 5) has reported also on this problem. In order

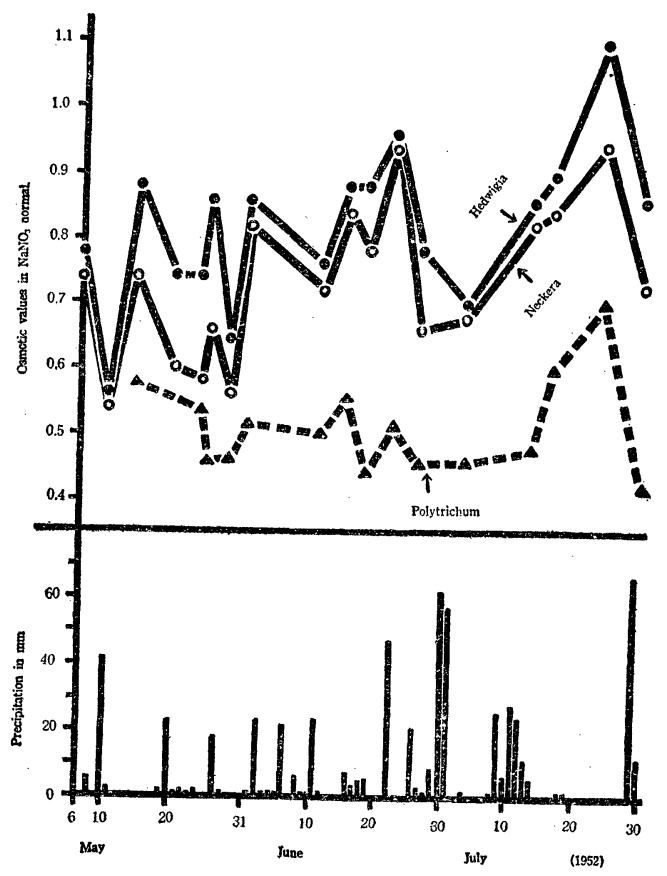

Fig. 2. Osmotic values at incipient plasmolysis and daily precipitation amount. to determine whether such refractoriness happened or not in the preceded experiments, the following experiments were conducted.

In parallel with experiment 3 , the incipient plasmolysis value was determined with a series of glucose solutions at $0.05 \mathrm{~mol}$. intervals (Fig. 3). The osmotic pressure of the corresponding concentrations of $\mathrm{NaNO}_{3}$ and glucose solutions were

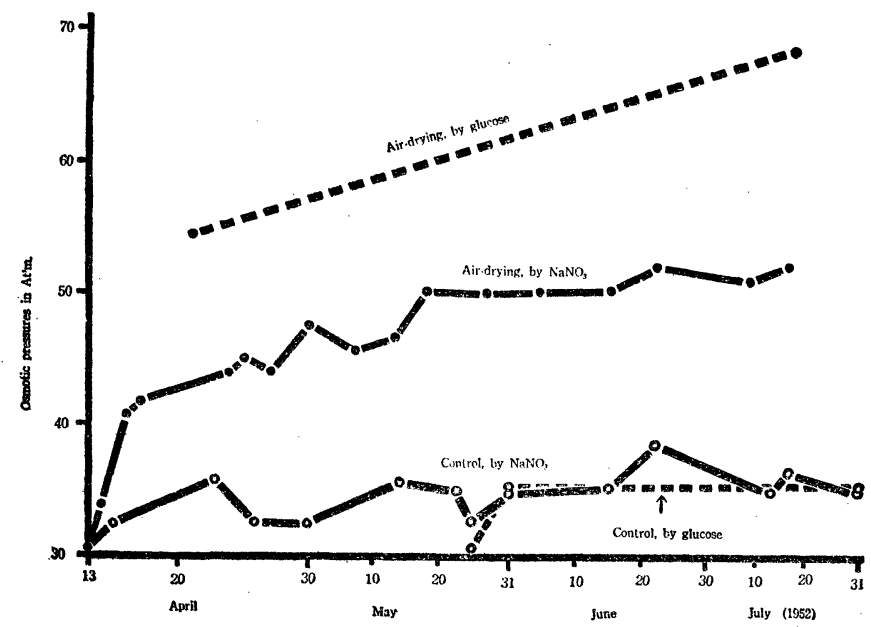

Fig. 3. Fluctuations of the osmotic pressure in Hedwigia in plants kept air-dried in the room and in the control. 
determined by the cryoscopic method.

As represented in Fig. 3, in the case of the control, the osmotic pressure determined by $\mathrm{NaNO}_{3}$ and glucose are approximately equal, on the other hand, in the case of air-dried material, they are higher by glucose than by $\mathrm{NaNO}_{3}$.

The investigation on the daily fluctuation of the osmotic value was also carried out, and almost no variances were recognized in all the employed spp.

\section{Discussions}

1. Through the results obtained from experiment 1 , the following explanations seem to be suitable concerning the fluctuation of the osmotic values in Hedwigia and Neckera.

Main factors affecting the osmotic values are the grade of maturity of the plant itself and temperature. Mature and temperature fall cause anatonosis and the reverse conditions cause catatonosis, and influences of the mature play more effective role than temperature.

The interval between January and April or May is considered as the interval of growth in length and of little maturing, on the other hand, temperature rises. Therefore, the osmotic value may descend slightly. In the interval between May and June or July, they abruptly mature, and consequently, the curve climbs steeply notwithstanding temperature rises. After June or July, the step in maturing and the variation of temperature are small, so the fluctuation almost stops for a while, but thereafter, temperature falls, so the curve goes upwards rapidly again until winter. The temporary decline in the osmotic value in December seems to be caused by high humidity of the habitat as described later.

In conclusion, mosses of the pollacauophytic type presumably indicate common pattern of the seasonal fluctuation of the osmotic value.

On the fluctuation of the osmotic value in Polytrichum, above explanations may partly be applicable, that is, the curve representing the interval between February and August resembles to the pollacauophytic species. But thereafter, it is kept at a constant level for a fairly long while notwithstanding temperature falls and plants perhaps continue to mature. To this fact, the authors can not give, at present time, any suitable explanations. The descension in December seems to be caused by the same reasons as mentioned in the pollacauophytic species.

In conclusion, at any rate, endohydric mesophytic mosses da not seem to represent so large seasonal fluctuation as pollacauophytic ones, as reported in the previous papers ${ }^{5), 8)}$.

2. Through the results obtained from experiment 2 , it is certain that the dry conditions cause anatonosis and the opposite conditions catatonosis, and that endohydric are not influenced so greatly as pollacauophytic species. This seems to be caused by the following reasons. Namely, the endohydric grows on soil and 
has well-developed rhizoid by which it is capable of absorbing water from the substratum, and causing active transpiratory stream in itself. Therefore, when vigorous transpiration takes place in dry conditions, water is continuously supplied from the substratum until available water is exhausted, so the plants are not subjected to abrupt drying. On the other hand, pollacauophytes grow on the bark of trees or on rock, and the water capacity of the substratum is very small, and plants have almost no special characters to prevent their water deficit, and have no active transpiratory stream. Accordingly, when water supply from the environment stops, the plants are obliged to go to their dry phase in a short while ${ }^{2), 6)}$.

Even the endohydric mesophytic moss is more shallow.rooted than endohydric vascular plants, so the former seems to be affected more strongly than the latter, and as we can see from Fig. 2, in Polytrichum, the osmotic value represents enormous ascension at the dry interval in July, and remarkable descension at the next rainy interval.

3. By means of keeping air-dried in the room, Hedwigia distinctly causes anatonosis, and this may indicate also an aquirement of the drought resistant nature?).

4. Through experiment 4, the accuracy of the data obtained from preceded experiments seems to be ascertained. Concerning the control, the osmotic pressures calculated from the corresponding concentrations of $\mathrm{NaNO}_{3}$ and glucose solutions at incipient plasmolysis in the same plant are approximately equal; and this seems to prove that no obstruction suggested by Brauner exists. And this concept may be assumed to be applicable to the results obtained from experiment 1 and 2 .

On the other hand, concerning the results obtained from experiment 3 , the refractoriness delivered by Patterson must be taken into consideration. On the material prepared for the experiment, however, Patterson's aspects on the refractoriness did not seem to be taken place when the leaves were immersed in $\mathrm{NaNO}_{3}$ solutions because the plasmolysis were determined with large cells at the leaf-base, and because it took plase during less than 15 to 30 minutes. When glucose was employed as the plasmolyzing agency, however, undoubtedly the osmotic value was abnormally higher than the concentration of the cell-sap. This is presumably caused by adhesion of the cytoplasm to the cell wall, or impermeability of the outer layer of the cell wall to glucose; because, when the material is air-dried, the cells undergo to shrink adhering the cytoplasm to the cell wall, and undergo to shrink especially on the outer layer of the cell wal12); and this abnormality perhaps takes place more greatly in the individuals adopted at July time than in those at April time.

\section{Summary and Conclusions}

1. The osmotic value of a few species of mosses were determined to make clear the effect of temperature and moisture of the habitats. Measurements were also 
made with the material while they were kept air-dried in the room.

2. The osmotic value seems to depend primarily on the grade of maturation of the plant itself, but it is affected also by moisture and temperature, contrary to the Bender's suggestion.

3. The osmotic value of pollacauophytic mosses are affected more greatlv by moisture than endohydric mesophytic ones.

The authors wish to express here their great indebtness to Dr. Jôji Ashida for his kind guidance and revision. of the manuscript. Thanks are also due to Miss Emiko Tanaka for her assistances in the experiments.

\section{Literature Cited}

1. Brauner, L. Pflanzenphysiologisches Praktikum, Teil 2. Jena: 28-29 (1932)

2. Buch, H. Soc. Sci. Fenn. Comm. Biol. 9, Nr. 16 \& 20 (1947)

3. Garjeanne, A. Verdoorn's Manual of Bryology, Netherland: 218 (1932)

4. Ochi, H. Liberal Arts Journ. $1: 18-26$ (1950)

5. ㄴ. Bot. Mag. Tokyo 65: 10-12 (1952)

6. - 1. c. $65: 112-118$ (1952)

7. - Bull. Soc. Plant Ecol. 1: 183-188 (1952)

8. Ochi, H. \& Iwanaga, M. Seibutsugakkaishi 2: 20-22 (1950)

9. Patterson, P. M. Amer. Journ. Bot. 33 : 604-611 (1946) 